\title{
Perinatal lethality and defects in hindbrain development in mice homozygous for a targeted mutation of the zinc finger gene Krox 20
}

\author{
Pamela J. Swiatek and Thomas Gridley ${ }^{1}$ \\ Roche Institute of Molecular Biology, Roche Research Center, Nutley, New Jersey 07110 USA
}

\begin{abstract}
Krox20 is a zinc finger gene expressed in rhombomeres 3 and 5 during hindbrain development in vertebrates. Mice homozygous for a targeted mutation that deletes the majority of the Krox20 gene, including the zinc finger DNA-binding domain, died shortly after birth. The primary phenotype of the homozygous mutant animals was the loss of rhombomeres 3 and 5 . This resulted in fusions of the trigeminal ganglion with the facial and vestibular ganglia, and of the superior ganglia of the glossopharyngeal and vagus nerves. These fusions resulted in a disorganization of the nerve roots of these ganglia as they entered the brain stem. These data demonstrate that Krox 20 plays an essential role during development of the hindbrain and associated cranial sensory ganglia in mice.
\end{abstract}

[Key Words: Hindbrain; rhombomeres; segmentation; Hox genes]

Received August 11, 1993; revised version accepted September 14, 1993.

Studies over the last several years have unequivocally shown that segmentation is a primary feature of the development of the hindbrain in vertebrates (for review, see Keynes and Lumsden 1990; Lumsden 1990; Wilkinson and Krumlauf 1990; Wilkinson 1993). The segmental pattern underlying vertebrate hindbrain development is indicated in several different ways. Morphologically, the vertebrate hindbrain transiently possesses a series of periodic swellings and constrictions, termed rhombomeres (Vaage 1969), and a number of features relating to neuronal development and hindbrain organization appear to be correlated with specific rhombomeres. Thus, studies in the chick have shown that differentiated neurons first appear in the even-numbered rhombomeres $|r| r 2, r 4$, and r6, before appearing in the odd-numbered rhombomeres (Lumsden and Keynes 1989). Structurally, each of the branchial motor nerves arises from a pair of rhombomeres: Cell bodies for the fifth nerve (V) are located in $\mathrm{r} 2 / \mathrm{r} 3$, those for the seventh nerve (VII) in $r 4 / \mathrm{r} 5$, and those for the ninth nerve (IX) in $\mathrm{r} 6 / \mathrm{r} 7$ (Lumsden and Keynes 1989).

The segmental pattern underlying vertebrate hindbrain development is also apparent at the level of gene expression. A number of genes have segmentally restricted patterns of expression in the developing vertebrate hindbrain. These genes include Hox homeo box genes (Murphy et al. 1989; Wilkinson et al. 1989b; Fro-

${ }^{1}$ Corresponding author. hman et al. 1990; Sundin and Eichele 1990; Hunt et al. 1991), retinoic acid receptors and the cellular retinoic acid-binding proteins (Smith and Eichele 1991; Maden et al. 1992; Ruberte et al. 1992), the receptor-type tyrosine kinase Sek (Nieto et al. 1992), the fibroblast growth factor family member Fgf3 (int2; Wilkinson et al. 1988), and the zinc finger gene Krox20 (Wilkinson et al. 1989a). The limits of expression of these genes coincide with rhombomere boundaries, providing molecular evidence that rhombomeres are true segmental compartments. In addition, the expression patterns of these genes suggest that at least some of them may play roles in establishing pattern and/or segment identity in the hindbrain.

As mentioned above, the zinc finger gene Krox20 is one of the genes expressed in a rhombomere-restricted fashion in the hindbrain. Krox 20 was originally cloned as an immediate-early response gene isolated from serumstimulated fibroblasts (Chavrier et al. 1988). The protein encoded by the Krox20 gene contains three $\mathrm{Cys}_{2} \mathrm{His}_{2}$ type zinc fingers, and several lines of evidence indicate that it acts as a transcription factor. Krox 20 protein binds to DNA in a sequence-specific manner (Chavrier et al. $1988,1990)$ and is able to trans-activate a promoter containing multiple Krox20-binding sites (Chavrier et al. 1990; Vesque and Charnay 1992). In the mouse, Krox20 is expressed early during hindbrain development in $\mathrm{r} 3$ and $\mathrm{r} 5$ (Wilkinson et al. 1989a). Expression in these rhombomeres is down-regulated and is subsequently followed by expression in two columns of cells in the hindbrain, which presumably correspond to specific hind- 
brain nuclei. Krox20 is also transiently expressed in a population of migrating neural crest cells adjacent to r6/7 and is later expressed in the neural crest-derived boundary cap cells of the cranial ganglia /Wilkinson et al. 1989a).

The Krox20 gene is evolutionarily conserved in vertebrates, and Xenopus, chick, human, and zebrafish Krox20 homologs have been cloned (Joseph et al. 1988; Nieto et al. 1991; Bradley et al. 1992; Oxtoby and Jowett 1993). In addition to amino acid sequence conservation, most aspects of the patterns of embryonic gene expression are also conserved in the vertebrate Krox20 homologs, suggesting a conserved role for these genes in hindbrain development (Wilkinson et al. 1989a; Nieto et al. 1991; Bradley et al. 1992; Oxtoby and Jowett 1993). In all vertebrates examined to date, expression of Krox20 genes is first detected, before the morphological appearance of rhombomeres, in two spatial domains in the hindbrain that are later seen to coincide with $\mathrm{r} 3$ and $\mathrm{r} 5$ (Wilkinson et al. 1989a; Nieto et al. 1991; Bradley et al. 1992; Oxtoby and Jowett 1993). Work in the chick has established that the appearance of rhombomere boundaries coincides with cell lineage restriction in the rhombomeres (Fraser et al. 1990). Thus, Krox20 expression is initiated before the appearance of lineage-restricted segmental compartments in the hindbrain. Recent work has demonstrated that Krox20 regulates the expression of the homeo box gene Hoxb-2 (Hox-2.8) (Sham et al. 1993). This suggests that Krox20 may exert its role during hindbrain development, at least in part, by regulating the expression of the Hox homeo box genes, which also display rhombomere-restricted patterns of expression in the hindbrain (Murphy et al. 1989; Wilkinson et al. 1989b; Frohman et al. 1990; Sundin and Eichele 1990; Hunt et al. 1991).

To begin to examine the role that the Krox20 gene plays during hindbrain development, we deleted most of the Krox20 gene by homologous recombination in embryonic stem (ES) cells and used these cells to generate mutant mice. Mice homozygous for this mutation die shortly after birth and exhibit major defects in the formation of the cranial sensory ganglia. In situ hybridization analysis indicated that these defects resulted from the loss of $\mathrm{r} 3$ and $\mathrm{r} 5$ in the homozygous mutant animals. This work establishes that the Krox20 gene plays an essential role during development of the hindbrain and associated cranial sensory ganglia in mice.

\section{Results}

Targeted disruption of Krox 20 and germ-line transmission of the mutated allele

A Krox20 genomic clone isolated from a strain 129 genomic library was used for construction of the targeting vector. The vector contained a neo expression cassette for positive selection and a herpes virus thymidine $\mathrm{ki}$ nase expression cassette for negative selection against random integration of the targeting vector (Mansour et al. 1988). The targeting vector contained $2.5 \mathrm{~kb}$ of homologous sequence $5^{\prime}$ and $3.4 \mathrm{~kb}$ of homologous sequence 3' of the neo cassette (Fig. 1). This construct deletes the carboxy-terminal 315 amino acids of the Krox 20 protein (Chavrier et al. 1988), which includes the three zinc fingers. We expect that this deletion should act as a null mutation, as the DNA-binding domain (the zinc finger region) (Vesque and Charnay 1992) is deleted. In addition, because the Krox 20 protein binds DNA as a monomer (Nardelli et al. 1991 1992; Pavletich and Pabo 19911, this mutation should not cause a dominant-negative effect. Because our targeting vector deletes the zinc finger region of the Krox 20 gene, we refer to this mutant allele as $\mathrm{Krox} 20^{\Delta z f}$.

The linearized targeting vector was electroporated into
Figure 1. Targeted disruption of the Krox20 gene. (A) Targeting scheme. The top line shows the genomic organization of the Krox20 gene (Chavrier et al. 1989). Exons are indicated by stippled boxes. The three zinc fingers in the second exon are indicated by a solid box. The middle line represents the structure of the targeting vector. An 800-bp deletion was created in exon 2 that removes the carboxy-terminal 315 amino acids of the Krox 20 protein, including the zinc finger DNA-binding domain. Shown at the bottom is the predicted structure of the Krox20 locus following homologous recombination of the targeting vector. Hybridization probes used for Southern blot analysis are indicated, as well as the expected sizes of hybridizing restriction fragments. Restriction enzymes: (B) BamHI; (E), EcoRI; (H) HindIII; (S) SfiI.

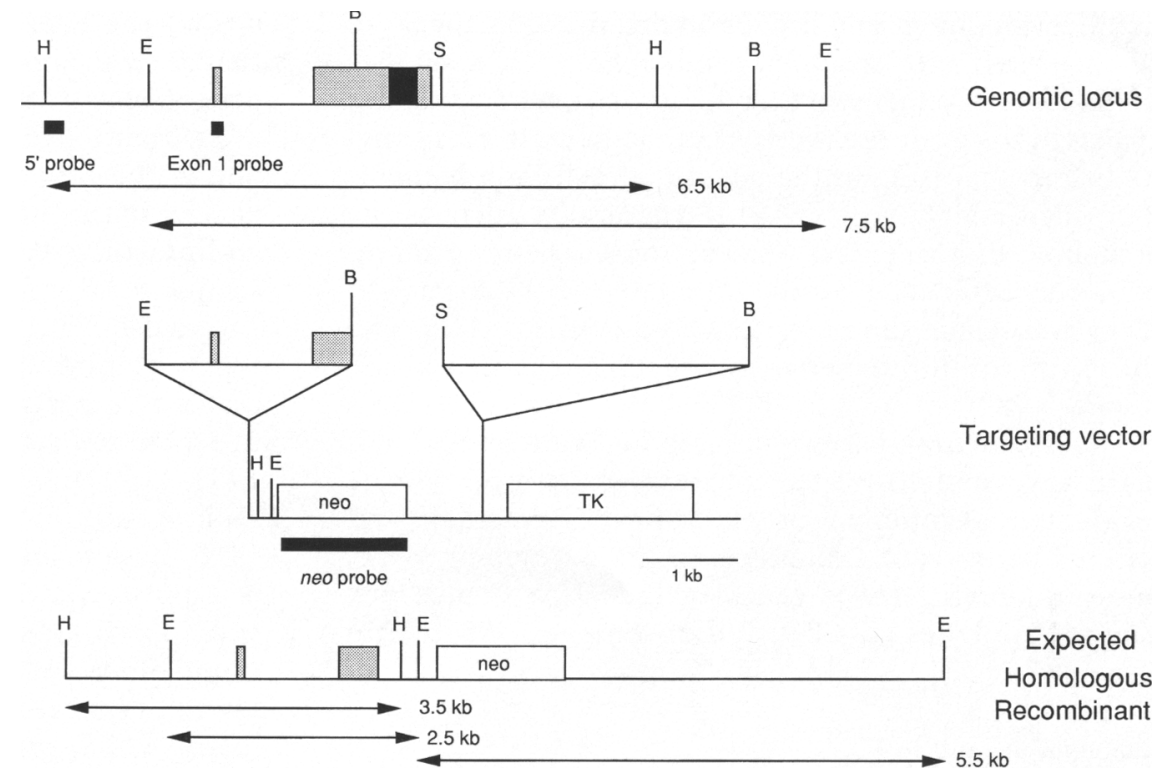


CJ7 ES cells (see Materials and methods for derivation of the cell line), and the electroporated cells were subjected to positive/negative selection (Mansour et al. 1988) using G418 and FIAU. Two independently targeted clones were identified by Southern blot screening, which represented a targeting frequency of $\sim 1 / 125$ double-selected clones. Mutant clones were expanded and confirmed by Southern analysis with various restriction enzymes (see Fig. 2). Mutant clones were injected into $\mathrm{C} 57 \mathrm{Bl} / 6$ recipient blastocysts, and male founder animals exhibiting extensive coat-color chimerism were crossed to C $57 \mathrm{Bl} / 6$ females. Because the ES cells were derived from 129/Sv mice, progeny of the chimeric founders were $F_{1}$ hybrids of the two strains. Germ-line transmission of the Krox $20^{\Delta z f}$ allele was obtained for both targeted clones. Krox $20^{\Delta z f}$ alleles passed through the germ line were analyzed by Southern blotting to confirm that they contained the expected replacement-type homologous recombination event (Fig. 2; also see Materials and methods). $\mathrm{F}_{1}$ mice heterozygous for the Krox $20^{\Delta z f}$ mutation appeared phenotypically normal.

\section{Mice homozygous for the Krox $20^{\Delta \mathrm{zf}}$ mutation die} shortly after birth

To examine whether mice homozygous for the Krox $20^{\Delta z f}$ mutation were viable, heterozygous $F_{1}$ animals were intercrossed and the genotypes of $F_{2}$ progeny were determined. Breeding and phenotypic analysis were carried out for both independently targeted Krox $20^{\Delta z f}$ alleles. No differences in the mutant phenotype described below were noted between mice derived from the two clones. Most mice $(\sim 70 \%)$ homozygous for the Krox $20^{\Delta z f}$ mutation died during the first $24 \mathrm{hr}$ after birth (Table 1). These animals appeared morphologically normal and were able to breathe but did not feed. A smaller proportion $(\sim 30 \%)$ of the homozygous animals lived for 5-10 days. These surviving Krox $20^{\Delta z f}$ homozygotes, however, were severely runted compared with heterozygous or wild-type

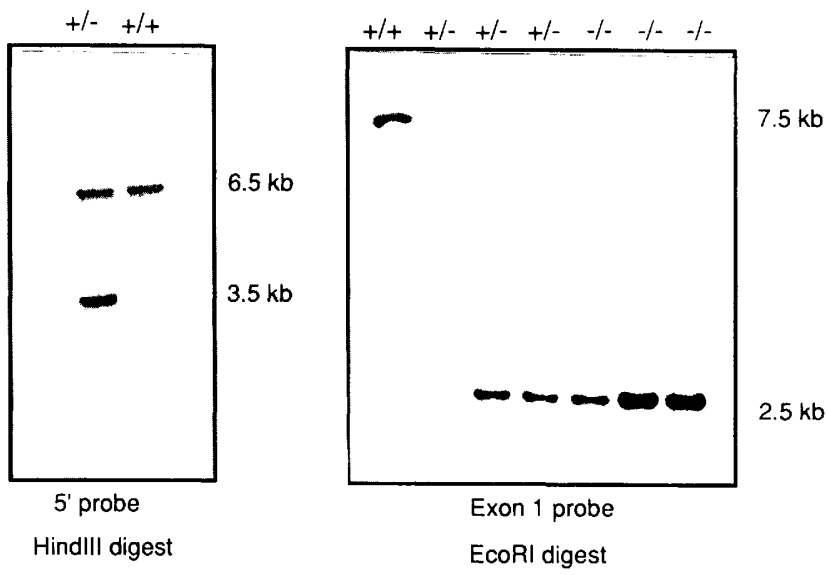

Figure 2. Southern blot analysis. DNA isolated from progeny of the intercross of $K r o x 20^{\Delta z f} /+$ heterozygous mice was digested with the indicated restriction enzymes, blotted, and hybridized with the indicated probes (Fig. 1). Sizes of hybridizing fragments are indicated. Genotypes of progeny are indicated at the top of the lane. littermates. No Krox20 $20^{\Delta z}$ homozygous animal has survived longer than 20 days, despite attempts to maximize their chances for survival (Table 1). This analysis was performed on a genetically segregating $\mathrm{F}_{2}$ generation. Although lethality was completely penetrant in $K r o \times 20^{\Delta z f}$ homozygotes, there was some variability in the time that the lethality occurred. At present, we do not know whether the variable penetrance in the time of lethality that we have observed would be reduced if the Krox $20^{\Delta z f}$ mutation was maintained on the inbred 129 /Sv background. We have not determined a specific cause of death for the Krox $20^{\Delta z f}$ homozygous animals, although it is likely that impaired ability to feed plays some role in the observed lethality (see Discussion).

\section{Mice homozygous for the Krox $20^{\Delta z \mathrm{z}}$ mutation exhibit defects in cranial nerves and ganglia}

Given the expression pattern of the Krox20 gene and the perinatal lethality observed in Krox $20^{\Delta z f}$ homozygous animals, we sought to determine whether there were detectable neuronal defects in the Krox $20^{\Delta z f}$ homozygotes. To assess the development of cranial nerves and ganglia, embryos from intercrosses of $\mathrm{Krox}_{2} \mathrm{O}^{\Delta z f} /+$ heterozygous mice were isolated at 9.5 and 10.5 days postcoitum (dpc) and were assayed by whole-mount immunohistochemistry with a monoclonal antibody to the $155-\mathrm{kD}$ neurofilament protein (Dodd et al. 1988). In wild-type embryos at $9.5 \mathrm{dpc}$, separate primordia for the trigeminal (V) and the combined facial/acoustic (VII/VIII) ganglia could be discerned clearly (Fig. 3A). At this stage of gestation the facial/acoustic ganglion complex appeared more condensed than the trigeminal ganglion, and it was clearly separated from the trigeminal by a zone free of neurofilament-positive cells (Fig. 3A). In Krox2 ${ }^{\Delta z f}$ homozygous mutant embryos at $9.5 \mathrm{dpc}$, the most striking defect was an expansion of the domain of the trigeminal ganglion so that it overlapped that of the facial/acoustic ganglion complex (Fig. 3B). In addition, the facial/acoustic ganglion complex of Krox $20^{\Delta z f}$ homozygotes appeared less condensed than that of wild-type embryos. These defects were bilateral in the Krox $20^{\Delta z f}$ homozygous mutant embryos.

In wild-type embryos at $10.5 \mathrm{dpc}$, in addition to the primordia of the cranial ganglia, axons associated with several of the cranial nerves were clearly visible (Fig. $3 \mathrm{C}$ ). The three divisions of cranial nerve $\mathrm{V}$ (the ophthalmic, maxillary, and mandibular divisions) could be seen emanating from the trigeminal ganglion. The facial (VII) nerve could be seen innervating the second branchial arch, and a zone free of neurofilament-positive cells still clearly separated the trigeminal ganglion from the facial/ acoustic ganglion complex (arrowhead in Fig. 3C). In addition, axons of the glossopharyngeal (IX) and vagus (X) nerves and their associated ganglia were then visible (Fig. $3 \mathrm{C})$. In Krox $20^{\Delta z f}$ homozygous mutant embryos at 10.5 $\mathrm{dpc}$, the zone free of neurofilament-positive cells that separates the trigeminal and facial/acoustic ganglia was no longer present, and these ganglia appeared to overlap one another (Fig. 3D,E). More distally, the seventh cra- 
Table 1. Genotypes of progeny of $F_{1}$ intercrosses of $\mathrm{Krox} 20^{\Delta z f} /+$ heterozygous mice

\begin{tabular}{|c|c|c|c|c|c|c|c|}
\hline \multirow[b]{2}{*}{ Clone } & \multirow[b]{2}{*}{$\begin{array}{l}\text { Number } \\
\text { of litters }\end{array}$} & \multirow[b]{2}{*}{$\begin{array}{l}\text { Total } \\
\text { mice }\end{array}$} & \multicolumn{5}{|c|}{ Genotypes } \\
\hline & & & $+1+$ & $+1-$ & $\begin{array}{l}-1- \\
\text { survive } \\
<24 \text { hours }\end{array}$ & $\begin{array}{l}-/- \\
\text { survive } \\
5-10 \text { days }\end{array}$ & $\begin{array}{l}-/- \\
\text { survive } \\
>2 \text { weeks }\end{array}$ \\
\hline $2-4 A$ & 8 & 55 & 18 & 22 & 10 & 4 & $1^{a}$ \\
\hline $3-5 \mathrm{~F}$ & 3 & 17 & 3 & 11 & 3 & 0 & 0 \\
\hline
\end{tabular}

This animal died at day 20 .

nial nerve (VII) and the three branches of the fifth nerve $(\mathrm{V})$ appeared unaffected in the Krox $20^{\Delta z f}$ homozygous mutant embryos. An additional defect observed in Krox $20^{\Delta z f}$ homozygotes at $10.5 \mathrm{dpc}$ was a fusion of the glossopharyngeal (IX) nerve with the vagus $(\mathrm{X})$ nerve complex (Fig. 3D,E). All of these defects were observed on both sides of the Krox $20^{\Delta z f}$ homozygous mutant embryos.

Histological sections of Krox $20^{\Delta z f}$ homozygous mutant embryos and control littermates were also examined. Embryos isolated at $12.5 \mathrm{dpc}$ were sectioned in transverse and frontal planes, and embryos isolated at $15.5 \mathrm{dpc}$ were sectioned in transverse, frontal, and sagittal planes. This analysis revealed that all Krox20 $0^{\Delta z f}$ homozygous mutant embryos exhibited the same basic defect: The trigeminal (V) ganglion of the mutants overlapped and intermingled with the facial (VII) and vestibulocochlear (VIII) ganglia. At $12.5 \mathrm{dpc}$, the trigeminal ganglion was seen to overlap the rostral portion of the vestibulocochlear ganglion (Fig. 4A,B). More caudally at $12.5 \mathrm{dpc}$, the vestibulocochlear ganglion is beginning to separate into distinct vestibular and cochlear components. This partitioning of the vestibulocochlear ganglion was unaffected in mutant embryos (Fig. 4C,D). The trigeminal ganglion also overlapped and appeared to intermingle (or fuse) with the facial ganglion (Fig. 4C-F). Formation of the seventh nerve (VII), however, appeared unaffected in the Krox $20^{\Delta z f}$ homozygous mutant embryos (Fig. 4C-F). Entry of the trigeminal nerve roots into the brain stem appeared very disorganized in mutant embryos (Fig. 4E,F).

Essentially the same phenotype was observed in mutant embryos isolated at $15.5 \mathrm{dpc}$ (Fig. 5). The trigeminal ganglion overlapped with both the facial ganglion and the vestibular ganglion, which is distinct from the cochlear ganglia, and the nerve roots of these ganglia appeared disorganized where they entered the brain stem (Fig. 5C,D). Despite the fusion of the glossopharyngeal (IX) nerve with the vagus (X) nerve complex observed in mutant embryos by anti-neurofilament immunohistochemistry (Fig. 3D,E), we did not detect by histological analysis of sectioned material any obvious abnormalities of the ninth and tenth cranial nerves (IX and X, respectively) or their associated superior and inferior ganglia (data not shown).

\section{Krox $20^{\Delta z f}$ homozygous mutant embryos lack $r 3$ and $r 5$}

To determine the cause for the fusions of cranial sensory ganglia observed in Krox $20^{\Delta z f}$ homozygous mutant mice, we performed in situ hybridization analyses with probes for several genes that are expressed in a segmentally restricted fashion in the developing hindbrain. Sham et al. (1993) recently reported convincing evidence that the Krox20 gene regulates expression of the Hoxb-2 (Hox2.8) gene. At $8.5 \mathrm{dpc}, H o x b-2$ is expressed at a uniform level in neuroepithelium, with an anterior boundary of expression that corresponds to the future $\mathrm{r} 2 / \mathrm{r} 3$ boundary. By $9.5 \mathrm{dpc}$, however, Hoxb-2 expression is up-regulated in $r 3, r 4$, and $r 5$. Krumlauf and colleagues have identified two enhancer elements in the Hoxb-2 gene responsible for this up-regulation (for review, see Krumlauf 1993). One element is responsible for the up-regulation in $\mathrm{r} 4$ (Marshall et al. 1992); the second element is responsible for the up-regulation in $\mathrm{r} 3$ and $\mathrm{r} 5$, and confers $\mathrm{r} 3 / \mathrm{r} 5$-restricted expression to a heterologous promoter in transgenic mice. They further identified Krox20-binding sites in this enhancer and demonstrated that the $\mathrm{r} 3 / \mathrm{r} 5$ restricted expression conferred by this enhancer was lost if the Krox20-binding sites were mutated (Sham et al. 1993).

We analyzed $H o x b-2$ expression by nonradioactive whole-mount in situ hybridization in Krox $20^{\Delta z f}$ homozygous embryos and wild-type littermates isolated at $9.0 \mathrm{dpc}$ (14-16 somites) (Fig. 6). Hoxb-2 expression in wild-type embryos appeared identical to the pattern described previously (Sham et al. 1993). Wild-type embryos had an anterior limit of Hoxb-2 expression at the $\mathrm{r} 2 / \mathrm{r} 3$ boundary (Fig. 6A). Expression in r3, r4, and $r 5$ was higher than in more posterior regions of the neural tube, and a column of neural crest cells expressing Hoxb-2 was observed migrating from $\mathrm{r} 4$ into the second branchial arch (Fig. 6A). In Krox20 $20^{\Delta z}$ homozygous embryos, no $H o x b-2$ expression was detectable in the region of the neural tube corresponding to $\mathrm{r} 3$ (Fig. 6B,C). Hoxb-2 expression in $\mathrm{r} 4$ and in the column of neural crest cells migrating from $\mathrm{r} 4$ was unaffected. Hoxb-2 was still expressed in the region of the neural tube corresponding to $\mathrm{r} 5$ in the Krox20 $20^{\Delta z f}$ homozygous embryos (Fig. 6B,C), although the level of expression was reduced compared with the intense band of $H o x b-2$ expression seen in $r 5$ in wild-type embryos (Fig. 6A; also cf. Fig. 1, C and D, in Sham et al. 1993).

Two possibilities could explain the Hoxb-2 expression pattern observed in the Krox $20^{\Delta z f}$ homozygous mutant embryos. The first possibility is that $\mathrm{r} 3$ and $\mathrm{r} 5$ are present in the homozygous mutants, but Hoxb-2 expression is down-regulated because of the lack of its transcriptional 

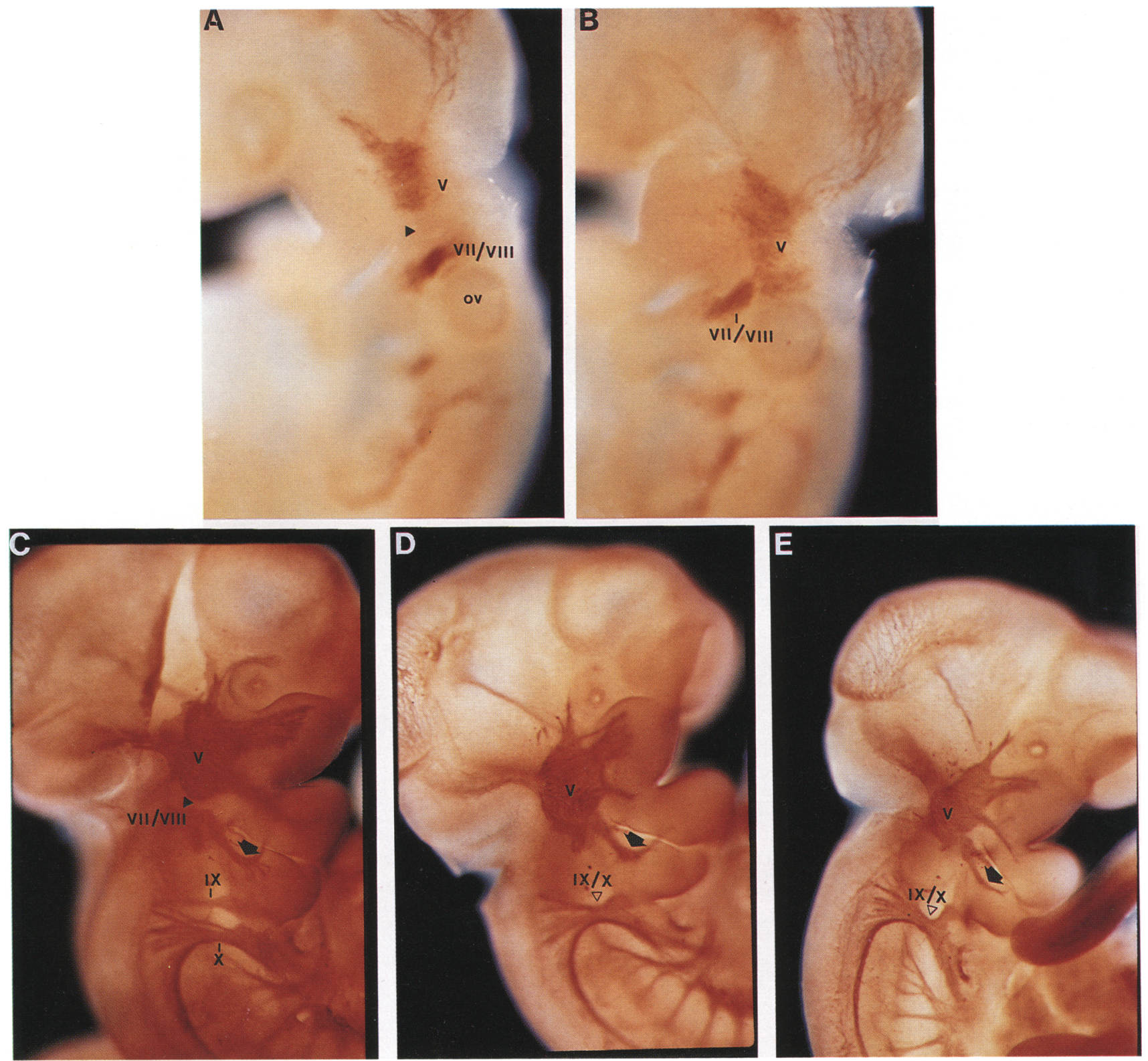

Figure 3. The Krox $20^{\Delta z f}$ mutation affects the formation of cranial ganglia. Whole-mount immunohistochemistry with an antineurofilament monoclonal antibody of $K r o x 20^{-1 z f}$ homozygous mutant embryos $(B, D, E)$ and wild-type littermates $\langle A, C)$. $|A, B| 9.5 \mathrm{dpc}$ embryos. A zone free of neurofilament-positive cells separating the condensing trigeminal ganglion from the facial/acoustic ganglion complex, which is present in the wild-type embryo (solid arrowhead in A), is absent in the Krox $20^{\perp z f}$ homozygous mutant embryo. In addition, the facial/acoustic ganglion complex in the mutant embryo is less condensed and is stained more lightly by the monoclonal antibody than the facial/acoustic complex of the wild-type littermate. $(C-E)$ 10.5-dpc embryos. The zone free of neurofilamentpositive cells (solid arrowhead in $C$ ) still clearly separates the trigeminal ganglion from the facial/acoustic ganglion complex in the wild-type embryo $(C)$. This zone is absent from the Krox $20^{\mathrm{sz} f}$ homozygous mutant embryos and the two ganglia overlap $(D, E)$. Distal portions of the facial nerve (arrows in $C-E$ ) and the three branches of the trigeminal nerve appear identical in the mutant and wild-type embryos. An additional defect observed in the Krox20 $20^{\text {tzf }}$ homozygotes was a fusion of the glossopharyngeal (IX) nerve with the vagus (X) nerve complex lopen arrowhead, $D, E)$. Cranial nerves and ganglia are designated with Roman numerals as follows: (V) Trigeminal, (VII/VIII) facial/acoustic; (IX) glossopharyngeal; (X) vagus. (ov) otic vesicle.

regulator. One problem with this interpretation is that Hoxb-2 expression is entirely absent at the expected position of $\mathrm{r} 3$, whereas it is present, albeit at a lower level, at the position of $r 5$. A second possibility is that $r 3$ and $r 5$ are missing in the Krox $20^{\text {dzf }}$ homozygous mutant embryos. In this case, the Hoxb-2 expression observed at the postion of $\mathrm{r} 5$ would actually be the expression normally observed in $\mathrm{r} 6$. 

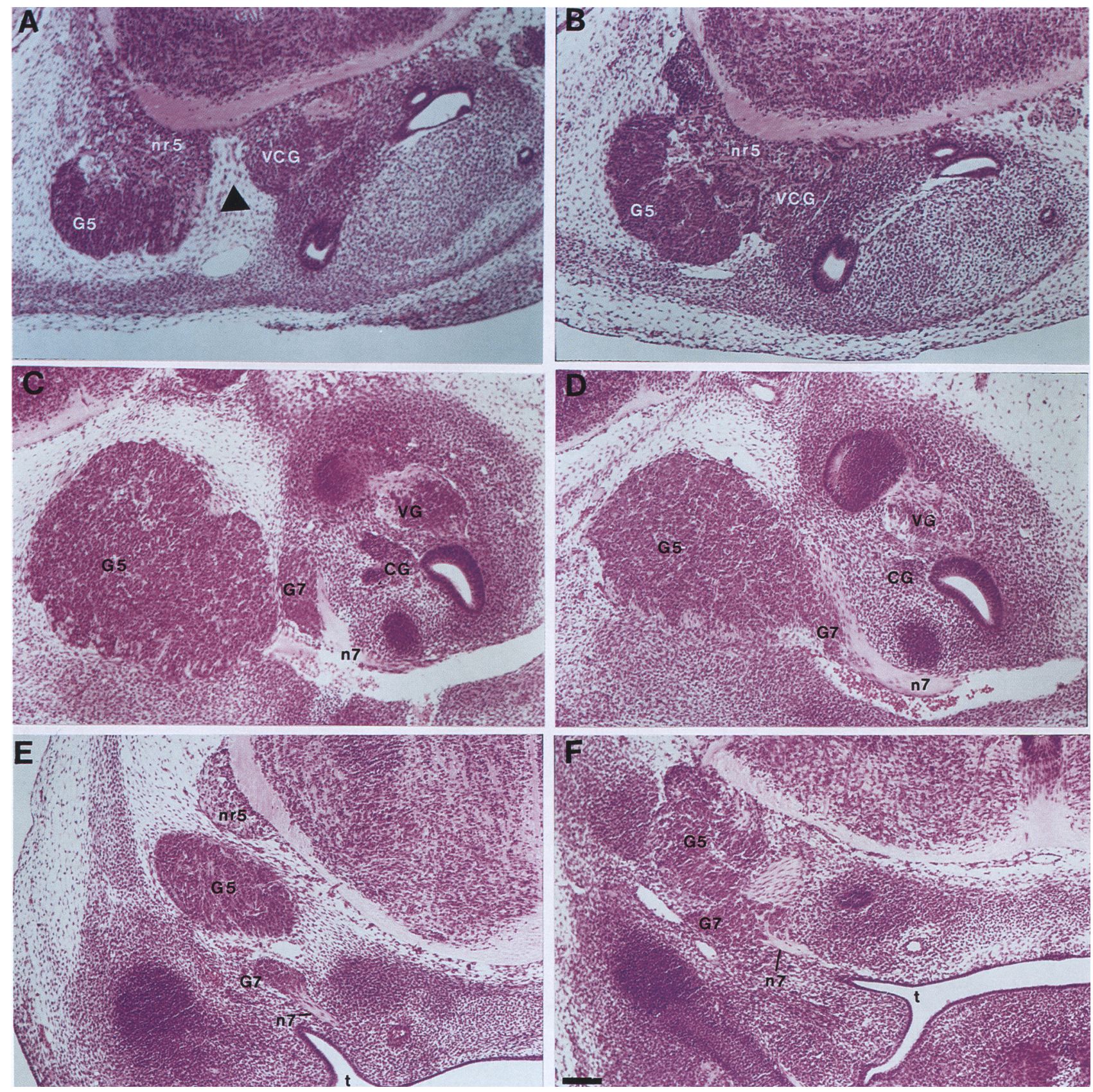

Figure 4. Histological analysis of Krox $20^{\Delta z f}$ homozygous embryos and control littermates at $12.5 \mathrm{dpc}$. Transverse $(A-D)$ and frontal $(E, F)$ sections through Krox $20^{\Delta z f}$ homozygous mutant embryos $(B, D, F)$ and wild-type $(A, C)$ or heterozygous $(E)$ littermates. $(A, B)$ Note that the neuron-free zone (solid arrowhead in $A$ ) present between the trigeminal ganglion and the vestibulocochlear ganglion complex in the wild-type embryo is absent in the Krox $20^{\Delta z f}$ homozygous mutant embryo. $(C, D)$ More caudal sections of the same embryos shown in $A$ and $B$. Note the fusion of the trigeminal and facial ganglia in the mutant embryo. Partitioning of the vestibulocochlear ganglion into distinct vestibular (VG) and cochlear (CG) components is unaffected in the mutant embryo, as is formation of the facial nerve $(\mathbf{n} 7) .\langle E, F\}$ Note again the fusion of the trigeminal and facial ganglia in the mutant embryo. The entry of the nerve roots of the trigeminal ganglion into the brain stem ( $\mathrm{nr} 5$ in $\mathrm{E}$ ) is very disorganized in the Krox $20^{\Delta-f}$ homozygous mutant embryos, and the trigeminal nerve roots appear to intermingle with nerve roots from the facial ganglion as they enter the brain stem. $(F)$ Bar, $100 \mu \mathrm{m}$ (applies to $A-E$ ). (CG) Cochlear component of the vestibulocochlear ganglion; (G5) trigeminal ganglion; (G7) facial ganglion; (n 7$)$ facial nerve; (nr5) nerve roots of the trigeminal nerve entering the brain stem; (t) tubotympanic recess; (VCG) vestibulocochlear ganglion; (VG) vestibular component of the vestibulocochlear ganglion.

To help distinguish between these possibilities, we performed in situ hybridization on embryo sections with radioactively labeled probes for several genes expressed in a segmentally restricted fashion in the developing hindbrain (Fig. 7). We chose to use radioactive probes on sectioned material for this analysis to enable us to test 

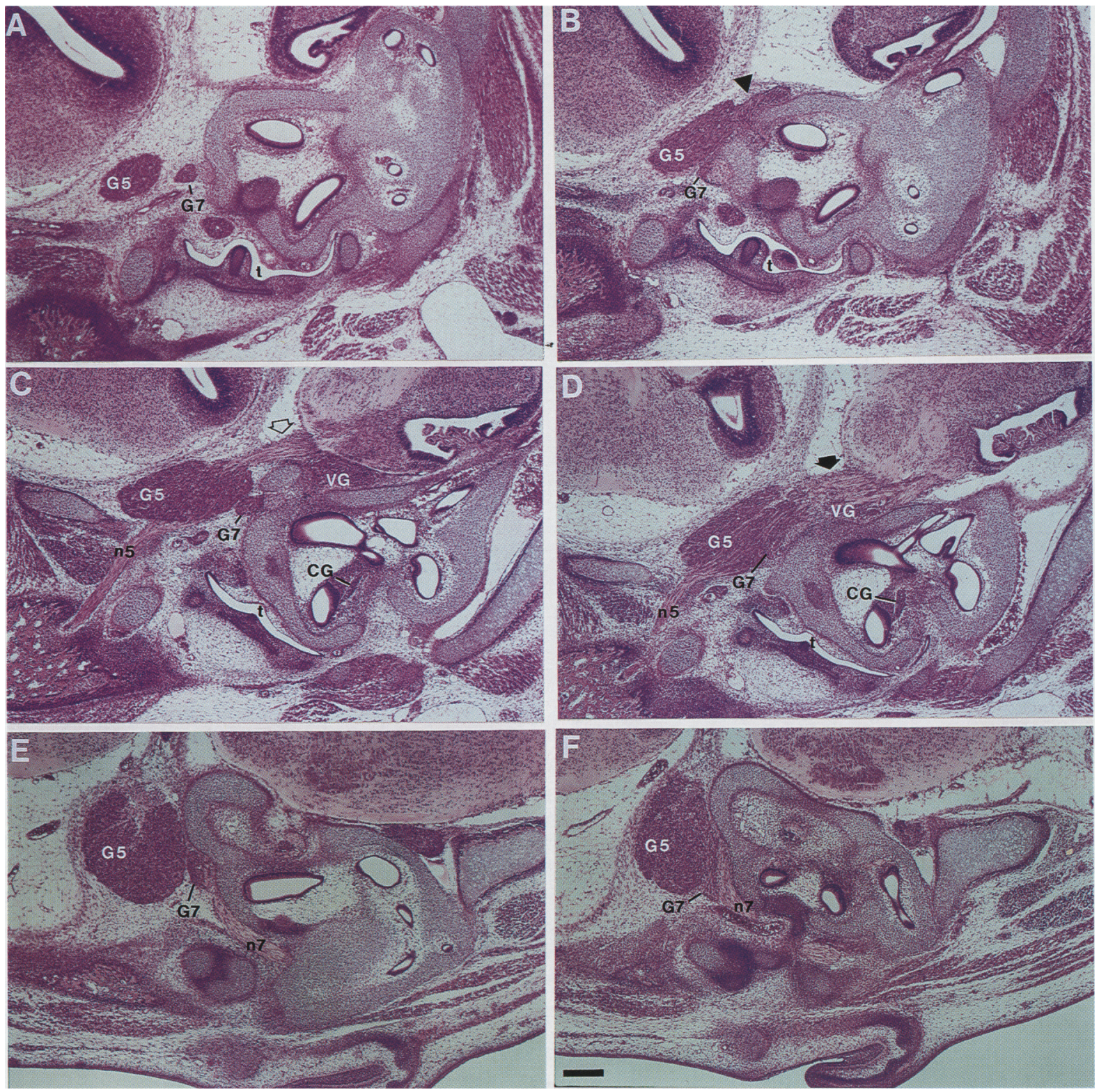

Figure 5. Histological analysis of Krox $20^{\text {tzf }}$ homozygous embryos and control littermates at 15.5 dpc. Sagittal $(A-D)$ and transverse $(E, F)$ sections through Krox20 $0^{\Delta z f}$ homozygous mutant embryos $(B, D, F)$ and wild-type $(A, C, E)$ littermates. $|A, B|$ Note that the enlarged domain (solid arrowhead, in $B$ ) of the trigeminal ganglion present in the Krox20.1zf homozygous mutant embryo overlaps the domain of the facial ganglion. The two ganglia are quite distinct in the wild-type embryo. $(C, D)$ More medial sections of the same embryos shown in $A$ and $B$. Note the well-organized entry of the proximal portion of the fifth cranial nerve (V) into the brain stem (open arrow, $C)$ in the wild-type embryo and the distinct facial and vestibular ganglia. In the Krox $20^{12 f}$ homozygous mutant embryo the trigeminal, facial, and vestibular ganglia all overlap, and the entry of these nerve roots into the brain stem appears disorganized (solid arrow in $D$ ). Note also that the cochlear (spiral) ganglia are unaffected in the mutant embryo. $(E, F)$ These panels represent similar planes of section to those in Fig. 4, C and D. Note again the fusion of the trigeminal and facial ganglia in the mutant embryo. $(F)$ Bar, $200 \mu \mathrm{m}(a p p l i e s$ to $A-F$ ). (CG) Cochlear (spiral) ganglion; (G5) trigeminal ganglion; (G7) facial ganglion; (n5) trigeminal nerve; (n7) facial nerve; $(\mathrm{t})$ tubotympanic recess; (VG) vestibular ganglion.

several different probes on each embryo. The probes used were cellular retinoic acid-binding protein I $(C R A B P I)$, $H o x b-1$, the receptor-type tyrosine kinase Sek, Fgf3 (int2), and a sense strand probe for Hoxb-3. The latter probe was used as a result of the serendipitous finding that the sense strand of $H o x b-3$ was expressed in $\mathrm{r} 4$ and $\mathrm{r} 6$ and was absent from $r 5$ (see Discussion). We therefore used hybridization of the sense strand of $H o x b-3$ as a marker for $\mathrm{r} 4$, $\mathrm{r} 5$, and $\mathrm{r} 6$. Hoxb-1 served as a marker for $\mathrm{r} 4$ (Murphy et al. 1989; Wilkinson et al. 1989b), whereas CRABP 
Figure 6. Krox $20^{\Delta z f}$ homozygous embryos exhibit altered expression of Hoxb-2. $(A-C)$ Whole-mount in situ hybridization with a $H o x b-2$ probe of Krox $20^{\Delta z f}$ homozygous mutant embryos $(B, C)$ and a wild-type littermate $(A)$. Note in all embryos Hoxb-2 expression in $\mathrm{r} 4$ and in a column of neural crest cells migrating from $r 4$ into the second branchial arch. The wild-type embryo exhibits Hoxb-2 expression in $\mathrm{r} 3$ lopen arrowhead, $A$ ) which is absent in the Krox20 $20^{\Delta f}$ homozygous embryos (solid arrowheads, $B$ and $C$ ). In addition, the intensity of Hoxb-2 expression in $\mathrm{r} 5$ in the Krox $20^{\Delta z f}$ homozygous embryos is reduced compared with the wild-type littermate.

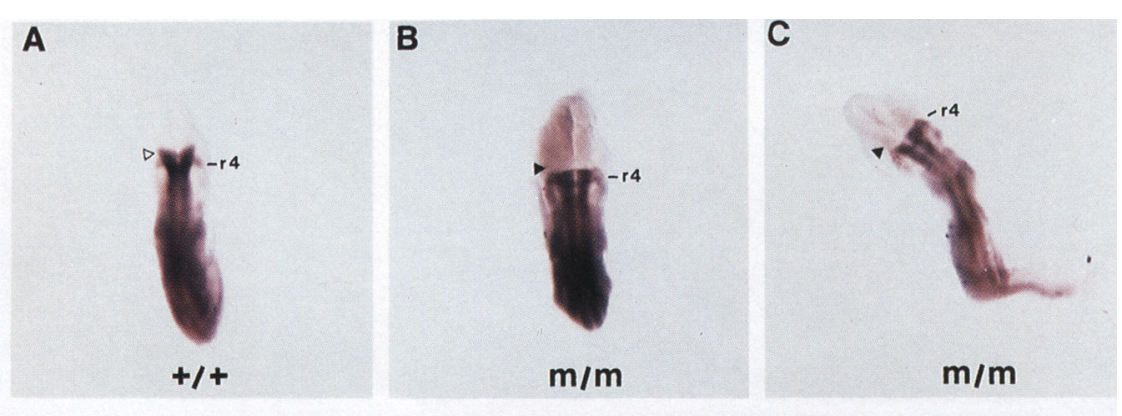

$I$ was particularly informative as a marker for $\mathrm{r} 3$ because in the ventral portions of the neural tube CRABP I expression diminishes in $\mathrm{r} 3$, while it is expressed at moderate levels in $\mathrm{r} 2$ and at high levels in $\mathrm{r} 4-\mathrm{r} 6$ (Maden et al. 1992; Ruberte et al. 1992). Sek expression was informative as a marker for several rhombomeres, as it is expressed at high levels in $\mathrm{r} 3$ and $\mathrm{r} 5$, at moderate levels in r2 and r6, and absent from r4 (Nieto et al. 1992). Fgf3 (int-2) was informative as a marker for $\mathrm{r} 5$ and $\mathrm{r} 6$ (Wilkinson et al. 1988).

Examination of this in situ hybridization data indicated that $\mathrm{r} 3$ and $\mathrm{r} 5$ are missing from Krox $20^{\Delta z f}$ homozygous mutant embryos by the 14-somite stage. The loss of r3 is demonstrated clearly by CRABP I hybridization (Fig. 7A,B). In the mutant embryo, the moderate expression domain of $\mathrm{r} 2$ directly abuts the high expression domain of $\mathrm{r} 4$, with no intervening domain of reduced expression $(\mathrm{r} 3)$. In addition, CRABP I-expressing neural crest cells can be seen migrating from the adjacent expression domains of $\mathrm{r} 2$ and $\mathrm{r} 4$ in the mutant embryo (Fig. $7 \mathrm{~B}$ ), with no crest-free zone separating them. Loss of $\mathrm{r} 5$ is demonstrated clearly by hybridization of the Hoxb-3 sense strand probe (Fig. 7I,J). The high Hoxb-3s expression domains of $\mathrm{r} 4$ and $\mathrm{r} 6$ abut directly in the mutant, with no intervening nonexpressing domain $\mid \mathrm{r} 5$ in the wild-type embryol. Loss of both $\mathrm{r} 3$ and $\mathrm{r} 5$ is also supported by Sek hybridization (Fig. 7E,F). The moderate expression domains of $\mathrm{r} 2$ and $\mathrm{r} 6$ abut the nonexpression domain of $\mathrm{r} 4$. The high-level Sek expression domains of $\mathrm{r} 3$ and $\mathrm{r} 5$ are lost in the mutant. Hybridization of Fgf3 (int-2) (Fig. 7G,H) also supports the loss of $\mathrm{r} 5$, as in the mutant the expressing domain appears shorter and the rhombomeric constriction separating $r 5$ and $r 6$ in the wild-type embryo is absent in the mutant. In summary, the data presented in Figures 6 and 7 indicate that, by 9.0 $\mathrm{dpc}$ (14-16 somites), r3 and r5 are absent from Krox $20^{\Delta z f}$ homozygous mutant embryos.

\section{Discussion}

In this report we have demonstrated that Krox20 plays an essential role during development of the hindbrain and associated cranial sensory ganglia in mice. Mice homozygous for a targeted mutation that deletes the majority of the protein coding capacity of the Krox 20 gene, including the zinc finger DNA-binding domain, die shortly after birth. These mice exhibit major defects in the formation of the cranial sensory ganglia. The primary phenotype observed in Krox $20^{\Delta z f}$ homozygous mutant embryos was an overlap and partial fusion of the trigeminal ganglion with the facial/acoustic ganglion complex. In addition, the proximal nerve roots emanating from these ganglia were disorganized and appeared to intermingle as they entered the brain stem. Krox $20^{\Delta z f}$ homozygous mutants also displayed a fusion of the glossopharyngeal nerve with the vagus nerve complex. We demonstrated further that the probable cause for this fusion of the cranial nerves and ganglia was the loss of $\mathrm{r} 3$ and $\mathrm{r} 5$ in Krox $20^{\Delta z f}$ homozygous mutant embryos.

This interpretation is supported by findings from a set of rhombomere transplantation experiments performed recently in the chick, as well as by findings from the treatment of vertebrate embryos with retinoic acid. Kuratani and Eichele (1993) found that when they removed

Figure 7. $\mathrm{r} 3$ and $\mathrm{r} 5$ are missing in Krox $20^{\Delta z f}$ homozygous embryos at $9.0 \mathrm{dpc}$. In situ hybridization analysis of Krox20 $2 z f$ homozygous mutant embryos $(B, D, F, H, J)$ and a wild-type littermate $(A, C, E, G, I)$ are shown. Coronal sections through the hindbrain of embryos isolated at $9.0 \mathrm{dpc}$ (14-16 somites) were hybridized with antisense riboprobes for $C R A B P I(A, B), H o x b-1(C, D)$, the receptor-type tyrosine kinase $\operatorname{Sek}(E, F), F g f 3($ int-2; G,H), and a sense-strand probe for Hoxb-3 $(H o x b-3 s ; 1, I)$. In all panels, anterior is to the right and the position of the otic vesicle is marked with an asterisk (*). Two homozygous mutant embryos (one in $B$ and $D$; the other in $F, H$, and $J$ were used. In the wild-type embryo, rhombomere boundaries are marked with arrowheads and are numbered. For the homozygous mutant embryos, rhombomere boundaries are marked with arrowheads and our interpretation of the rhombomere identity, based on marker gene expression patterns, is indicated as the prime of the rhombomere number le.g., $4^{\prime}$ indicates $r 4$ of the homozygous mutant embryol. 
Hindbrain defects in Krox20 mutant mice

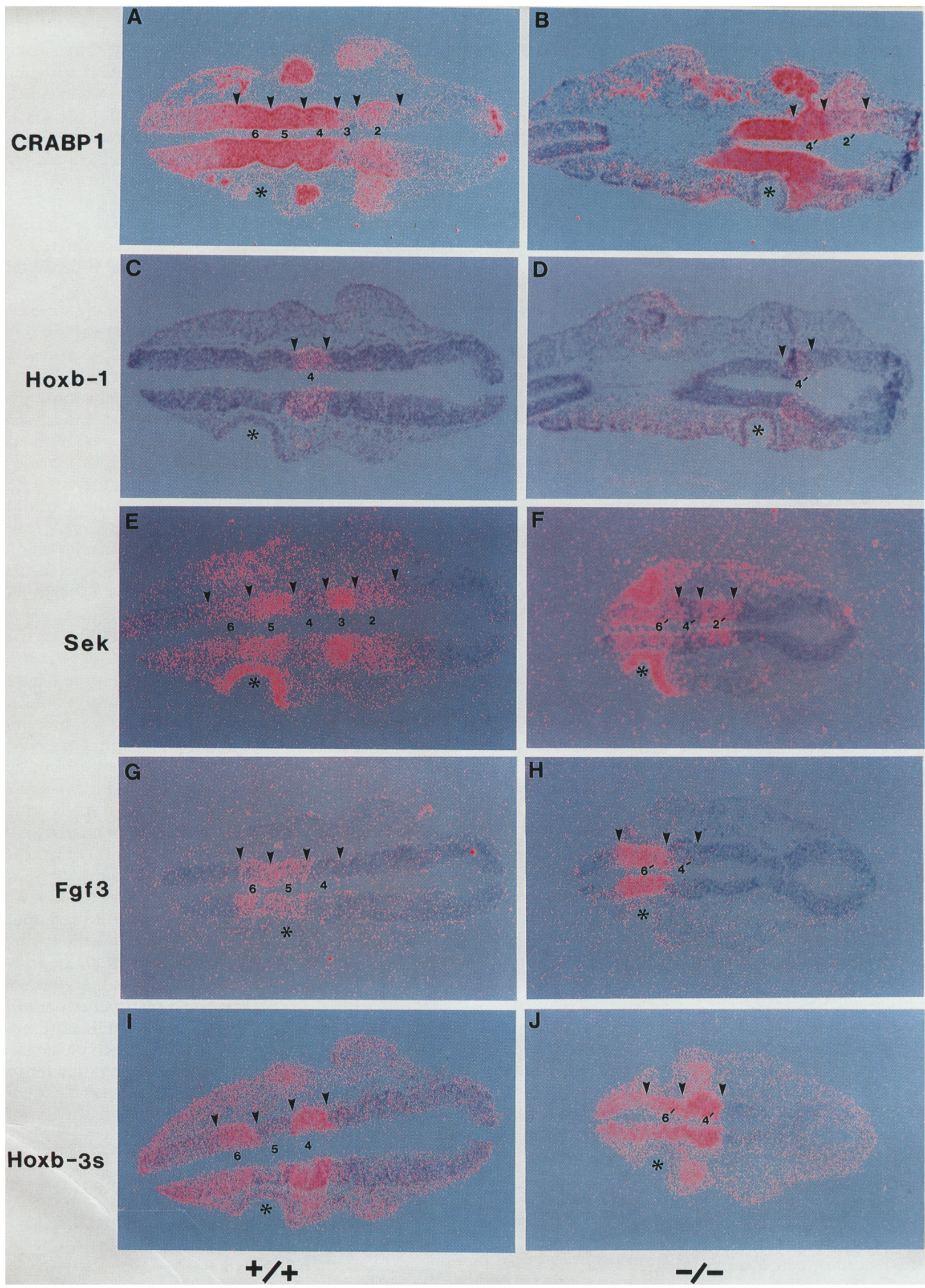

Figure 7. (See facing page for legend.) 
r3 from chick embryos and grafted $r 4$ in its place, fusion of the trigeminal and facial/acoustic ganglia occurred. This result is strikingly similar to the phenotype observed in Krox $20^{\Delta z f}$ homozygous mutants. Alternatively, when $r 3$ was grafted in place of $r 7$ in the chick experiments, a nerve-free gap resulted within the glossopharyngeal/vagus nerve root (Kuratani and Eichele 1993). r3, therefore, will apparently inhibit the formation of neurofilament-positive cells in the periphery, and this property is autonomous to the neuroepithelium of $\mathrm{r} 3$, as it is not altered upon transplantation. Further support for our interpretation of the phenotype of Krox $20^{\Delta z f}$ homozygous mutants comes from the analysis of embryos treated with retinoic acid. Retinoic acid treatment of vertebrate embryos can lead to fusions of cranial nerves and ganglia and also causes alterations in the expression patterns of Krox20 and some of the Hox homeo box genes (Morriss-Kay et al. 1991; Papalopulu et al. 1991; Conlon and Rossant 1992; Marshall et al. 1992; Sundin and Eichele 1992; Kessel 1993; for reviews, see Maden and Holder 1992; Morriss-Kay 1992). Recent work analyzing the effects of retinoic acid administration on embryonic development in mice suggested that $\mathrm{r} 2 / \mathrm{r} 3$ adopted an $\mathrm{r} 4 / \mathrm{r} 5$ identity in treated embryos. This transformation was indicated by the duplication of $\mathrm{r} 4 / \mathrm{r} 5 \mathrm{ex}-$ pression markers in $\mathrm{r} 2 / \mathrm{r} 3$, as well as by the morphological transformation of the cranial nerve emanating from $\mathrm{r} 2 / \mathrm{r} 3$ from a trigeminal to a facial identity (Marshall et al. 1992; for review, see Krumlauf 1993|. Thus, retinoic acid administration may also lead to a loss of $\mathrm{r} 3$ and can lead to fusions of the cranial ganglia similar to that observed in Krox $20^{\Delta z f}$ homozygous mutant embryos.

Interestingly, a mutation in another gene expressed in the hindbrain can also lead to fusions of cranial sensory ganglia. One of the groups that made mice mutant in Hoxa-1 (Hox-1.6) reported fusions in mutant embryos of both the trigeminal and facial/acoustic ganglia and the glossopharyngeal and vagus complexes, a phenotype very similar to that observed in Krox $20^{\Delta z f}$ homozygous mutant embryos (Chisaka et al. 1991). The other group that made a targeted mutation of Hoxa-1 did not report such fusions (Lufkin et al. 1991).

The formation of $\mathrm{r} 3, \mathrm{r} 4$, and $\mathrm{r} 5$ may be pivotal for proper development of the hindbrain. In the chick, where it has been studied most extensively, formation of rhombomere boundaries takes place in a defined sequence (Vaage 1969). $\mathrm{r} 3$ is the first rhombomere for which both anterior and posterior boundaries form (Vaage 1969; see Fig. 2 in Lumsden 1990), and the next boundary to form completes the central set of $r 3, r 4$, and $r 5$. A large number of observations indicate that $\mathrm{r} 3$ and $\mathrm{r} 5$ have different properties than other rhombomeres. For example, the appearance of differentiated neurons is delayed in $\mathrm{r} 3$ and $\mathrm{r} 5$ compared with the even-numbered $\mathrm{r} 2$, r4, and $\mathrm{r} 6$ (Lumsden and Keynes 1989). r3 and r5 may also have cell-surface properties that differ from those of even-numbered rhombomeres. In grafting experiments in the chick, Guthrie and Lumsden demonstrated that the juxtaposition of $\mathrm{r} 3$ with $\mathrm{r} 5$ did not generate a new boundary, even though the juxtaposition of either of these rhombomeres with an even-numbered rhombomere did generate a boundary (Guthrie and Lumsden 1991; Lumsden and Guthrie 1991). r3 and r5 have been found to coincide with localized areas of cell death, as assayed by nile blue sulfate staining (Lumsden et al. 1991; Jeffs et al. 1992). In addition, it has been reported that in the chick, r3 and r5 do not produce migratory neural crest cells (Lumsden et al. 1991), although recent work in several vertebrate species contradicts these results (Bradley et al. 1992; Serbedzija et al. 1992; Oxtoby and Jowett 1993; Sechrist et al. 1993; Sham et al. 1993). Our results demonstrate that expression of the Krox20 gene is required for development of $\mathrm{r} 3$ and $\mathrm{r} 5$.

The discovery that the nominal noncoding strand (i.e., detected with hybridization of the sense strand in situ hybridization probe) of the Hoxb-3 gene is expressed in $\mathrm{r} 4$ and $\mathrm{r} 6$ is a curious finding. Extensive analysis of the Hoxb-3 transcription unit had shown that multiple alternatively spliced transcripts from the coding strand were present (Sham et al. 1992). Examination of the noncoding strand of the mouse Hoxb-3 cDNA reveals the presence of a 169-amino-acid open reading frame (data not shown), most of which is conserved in the human Hoxb-3 gene (Acampora et al. 1989). This open reading frame, however, does not have any significant homology to any entries in the nucleic acid and protein sequence data bases. Experiments are in progress to learn more about this transcript from the noncoding strand. Presently, however, this transcript serves as a very useful marker for the presence or absence of $r 4, r 5$, and $r 6$.

We have not determined a specific cause of death for the Krox $20^{\Delta z f}$ homozygous animals. However, the cranial nerves and ganglia provide both motor and sensory innervation for the head and neck, as well as autonomic control over visceral functions such as breathing, heart rate, and swallowing (for review, see Role and Kelly 1991). Examination of Krox $20^{\Delta z f}$ homozygous mutant embryos revealed major defects in several cranial ganglia and the connection of the nerve roots of these ganglia to the brain stem. The trigeminal and facial ganglia were affected most severely. Among its many functions, the trigeminal nerve carries the sensory innervation of most of the oral mucosa and the anterior portion of the tongue, whereas trigeminal motor neurons innervate muscles responsible for mastication (Williams and Warwick 1980; Dodd and Kelly 1991). The facial nerve is also a mixed nerve and provides sensory innervation of part of the tongue, transmits parasympathetic innervation of the salivary glands, and provides motor innervation for muscles of the face (Williams and Warwick 1980; Role and Kelly 1991). Defects in both of these cranial nerves and ganglia would be expected to severely compromise the ability of the animal to feed. The majority of Krox $20^{\Delta z f}$ homozygous mutant animals die during the first $24 \mathrm{hr}$, without having fed. Mutant animals that survive for a week or two are runted severely at all stages compared with heterozygous and wild-type littermates. Thus, it seems likely that impaired ability to feed strongly contributes to the perinatal lethality observed in $\operatorname{Krox} 20^{\Delta z f}$ homozygous mutant animals. 


\section{Materials and methods}

\section{Derivation of ES cell lines}

For low-passage-number ES cell lines to be used in these experiments, new ES cell lines were derived essentially as described (Robertson 1987). Cell lines were derived both from normal and implantationally delayed blastocysts from agouti $129 / \mathrm{Sv}$ mice cultured on feeder layers of mitomycin C-treated primary embryonic fibroblast (PEF) cells in media containing $1000 \mathrm{U} / \mathrm{ml}$ of recombinant leukemia inhibitory factor (LIF) (ESGRO; GIBCO). Male ES cell lines were identified by Southern blot analysis using the Y chromosome-specific probe pY2 (Lamar and Palmer 1984) and were tested for germ-line transmission by blastocyst injection. Several cell lines gave good germ-line transmission, and one of these, the CJ7 line, was used for these experiments.

\section{Targeting vector construction}

A strain 129 mouse genomic phage library (Stratagene) was screened with a probe encompassing nucleotides 2417-2789 in the 3 '-untranslated region of the Krox 20 cDNA (Chavrier et al. 1988). This probe was made by using PCR to amplify this fragment from genomic DNA (Chavrier et al. 1989). Hybridizing phage were purified and phage inserts were subcloned into pGem $7 \mathrm{Zf}(+)$ (Promega). The identity of hybridizing clones was confirmed by nucleotide sequencing. To construct the targeting vector, we utilized the neo expression cassette from PGKneobpa (Soriano et al. 1991). A 2.5-kb EcoRI-BamHI fragment from the $5^{\prime}$ end of the Krox20 gene was blunt-end-ligated into a ClaI site upstream of the pGKneobpa cassette, and a 3.4-kb Sfil-BamHI fragment just 3 ' to the Krox20 gene was blunt-end-ligated into a NotI site downstream of the pGKneobpa cassette. This resulted in an 800-bp deletion in exon 2 that removes the carboxyterminal 315 amino acids of the Krox 20 protein, including the zinc finger DNA-binding domain. To permit negative selection against random integration of the targeting vector, a pMCIHSVTK cassette (Mansour et al. 1988) was introduced 3' to the Krox20 Sfil-BamHI fragment.

\section{Electroporation and selection of ES cells}

CJ7 cells were routinely cultured on mitomycin C-treated PEF feeder layers in Dulbecco's modified Eagle medium ((DMEM) high glucose formulation; GIBCO] supplemented with $15 \%$ fetal bovine serum (FBS) (HyClone), $1000 \mathrm{U} / \mathrm{ml}$ of recombinant LIF (ESGRO; GIBCO), and additional supplements (nonessential amino acids, $\beta$-mercaptoethanol, nucleosides, and antibiotics) as described (Robertson 1987). CJ7 ES cells at passage 3-4 were trypsinized and resuspended in phosphate-buffered saline (PBS) at $1.2 \times 10^{7}$ cells $/ \mathrm{ml}$. The resuspended cells $(0.75 \mathrm{ml})$ were electroporated with $25 \mu \mathrm{g}$ of linearized targeting vector DNA using a Bio-Rad Gene Pulser $(500 \mu \mathrm{F}, 240 \mathrm{~V})$. After electroporation, cells were plated into four $6-\mathrm{cm}$ tissue culture dishes containing mitomycin C-treated PEF feeder layers prepared from a transgenic mouse line that constitutively expresses the neomycin resistance gene (Stewart et al. 1992). After $24 \mathrm{hr}$, media in the dishes were removed and replaced with selection media containing, in addition to the routine supplements, $350 \mu \mathrm{g} / \mathrm{ml}$ of G418 (GIBCO) (as dry powder) and $0.5 \mu \mathrm{m}$ FIAU [1-(2-deoxy, 2-fluoro- $\beta$-D-arabinofuranosyl)-5 iodouracil; Bristol-Myers Squibb]. Media on the plates were changed daily. After 4 days, FIAU selection was stopped and media were replaced with selection media containing only $350 \mu \mathrm{g} / \mathrm{ml}$ of G418. Colonies were picked individually on days 6 and 7, disaggregated in trypsin-EDTA, and plated into wells of 48-well tissue culture plates containing PEF feeder cells.
Screening of G418-resistant colonies

For screening, ES cell clones in the 48-well dishes were trypsinized, and $1 / 3$ of the well was replica plated into a new 48-well dish without feeder cells and grown for DNA isolation. To the remaining $2 / 3$ of the ES cell clone in the 48-well dish, an equal volume of $2 \times$ freezing solution (20\% DMSO, 20\% FBS, $60 \%$ DMEM prepared without sodium bicarbonate and containing $10 \mathrm{~mm}$ HEPES buffer) was added and the plate was frozen at $-80^{\circ} \mathrm{C}$. DNA for Southern analysis was prepared from colonies in the replica plates by the method of Laird et al. (1991).

\section{Genotyping ES cell lines and mice by Southern analysis} and $P C R$

DNA was isolated from the mutant ES cell lines and tail biopsy samples using standard procedures (Sambrook et al. 1989). Embryos were genotyped using yolk sac DNA. Yolk sacs were incubated under mineral oil in 40-100 $\mu$ l of lysis buffer [50 mM $\mathrm{KCl}, 10 \mathrm{mM}$ Tris- $\mathrm{HCl}$ (pH 8.3), $2 \mathrm{mM} \mathrm{MgCl}_{2}, 0.45 \% \mathrm{NP}-40$, $0.45 \%$ Tween $20,60 \mu \mathrm{g} / \mathrm{ml}$ of proteinase $\mathrm{K}$ ] at $55^{\circ} \mathrm{C}$ overnight. The proteinase $\mathrm{K}$ was inactivated by heating the lysates at $94^{\circ} \mathrm{C}$ for $30 \mathrm{~min}$, and the lysates were genotyped using PCR or Southern analysis. PCR primers for the wild-type Krox20 allele were 5'-GCAGAAGGAACGGAAGAGCAG-3', located 3 ' to the zinc finger domain in a region deleted in the targeting construct, and 5'-ATCAAGGTCCTTTGCCCAGATC-3', located downstream of the Sfil site. PCR primers for the Krox $20^{\Delta z f}$ mutant allele were 5'-TCGCAGCGCATCGCCTTCTATCG-3', located in the neo gene, and 5'-ATCAAGGTCCTTTGCCCAGATC-3', located downstream of the SfiI site in the wild-type Krox20 locus. The PCR mixture consisted of $20 \mu \mathrm{l}$ of lysis buffer, $2 \mu \mathrm{l}$ of $10 \times$ PCR buffer, [166 mM $\left(\mathrm{NH}_{4}\right)_{2} \mathrm{SO}_{4}, 670 \mathrm{mM}$ Tris- $\mathrm{HCl}$ (pH 8.8), $1 \mathrm{mg} / \mathrm{ml}$ of BSA], $200 \mu \mathrm{M}$ each dNTP, $200 \mathrm{ng}$ of each primer, and $2 \mathrm{U} / \mu \mathrm{l}$ of Taq polymerase (Cetus) in a final volume of $40 \mu \mathrm{l}$. Temperature cycling conditions were $95^{\circ} \mathrm{C}, 30$ sec, $65^{\circ} \mathrm{C}$ for $30 \mathrm{sec}$, and $72^{\circ} \mathrm{C}$ for $90 \mathrm{sec}$ for 40 cycles. PCR products were resolved on $1 \%$ agarose gels.

Krox $20^{\mathrm{Lzf}}$ alleles passed through the germ line were analyzed by Southern blotting to confirm that they contained the expected replacement-type homologous recombination event. For Southern analysis, $10 \mu \mathrm{g}$ of DNA was digested with the restriction enzymes EcoRI or HindIII. The DNA was fractionated on a $0.8 \%$ agarose gel, transferred to ZetaProbe GT membranes (BioRad), and hybridized with the indicated probes (Fig. 1). The 5' probe was a HindIII-EcoRV genomic subclone. The exon 1 probe was a 155-bp fragment amplified by PCR from genomic DNA (Chavrier et al. 1989), and the neo probe was the XhoI fragment of pGKneobpa (Soriano et al. 1991). Both the 5' and 3' sides of the recombinant Krox $20^{\Delta z f}$ alleles were checked using enzymes that flanked the integration event. The $5^{\prime}$ side was checked with the $5^{\prime}$ and exon I probes (Fig. 2). The $3^{\prime}$ side was checked by hybridization of EcoRI-digested DNA with the neo probe. This gave the expected $5.5-\mathrm{kb}$ hybridizing band present only on the Krox $20^{4 z f}$ chromosome (data not shown). Hybridization and washing conditions were as described by the membrane supplier.

\section{Blastocyst injection and animal breeding}

Wells from the replica plate that screened positive for homologous recombination at the Krox20 locus were identified, and the corresponding well on the master plate was thawed and the mutant ES cell clone was expanded on PEF feeder cells for injection and DNA isolation. Mutant ES cells were trypsinized, centrifuged, and resuspended in injection medium (DMEM pre- 
pared without sodium bicarbonate and containing $10 \mathrm{mM}$ HEPES buffer and $10 \%$ FBS). Ten to fifteen ES cells were injected into the blastocoel cavity of 3.5 -dpc blastocysts from C57B1/6J mice. Injected blastocysts were surgically transferred into the uteri of pseudopregnant B6CBAF1/J (Jackson Laboratories/ recipients at $2.5 \mathrm{dpc}$. Male chimeras with extensive ES cell contribution to the coat were bred with $\mathrm{C} 57 \mathrm{Bl} / 6 \mathrm{~J}$ females to test for germ-line transmission of the dominant agouti coat color marker. $\mathrm{F}_{1}$ animals heterozygous for the Krox $20^{\Delta z f}$ allele were intercrossed.

\section{Histological analysis}

Embryos were dissected and DNA was prepared from the yolk sacs for genotyping by PCR or by Southern blot analysis. Embryos for histological analysis were fixed in Bouin's solution. Embryos for in situ hybridization were fixed overnight at $4^{\circ} \mathrm{C}$ in $4 \%$ paraformaldehyde in PBS. Fixed embryos were dehydrated through graded alcohols, embedded in paraffin, sectioned at 6-10 $\mu \mathrm{m}$ (depending on age), and stained with hematoxylin and eosin.

\section{Whole-mount immunohistochemistry}

Whole-mount immunohistochemistry with the monoclonal antibody $2 \mathrm{H} 3$, which recognizes a $155-\mathrm{kD}$ neurofilament protein (Dodd et al. 1988) (obtained from the Developmental Studies Hybridoma Bank, maintained by the Department of Biology, University of Iowa, Iowa City, IA, under contract from the National Institute of Child Health and Human Development (NICHD), was performed according to a protocol kindly supplied by Dr. Andrew Lumsden (Lumsden and Keynes 1989). Embryos at 9.5 and $10.5 \mathrm{dpc}$ were dissected from the decidua, and DNA was prepared from the yolk sacs for genotyping. Embryo heads were opened along the dorsal midline to allow penetration of reagents, and embryos were fixed in $4 \%$ paraformaldehyde in PBS for $4 \mathrm{hr}$ at $4^{\circ} \mathrm{C}$. Embryos were washed three times for $60 \mathrm{~min}$ in PBS. Endogenous peroxidases were blocked by incubating the embryos overnight at $4^{\circ} \mathrm{C}$ in PBS containing $0.1 \%$ hydrogen peroxide, $1.0 \%$ Triton $\mathrm{X}-100,5 \%$ calf serum. Embryos were then washed three times for $60 \mathrm{~min}$ in PBS containing $1.0 \%$ Triton X-100,5\% calf serum. For incubation of embryos with $2 \mathrm{H} 3$ monoclonal antibody, fresh hybridoma supernatant was mixed with an equal volume of DMEM / without sodium bicarbonate) containing 10 mM HEPES, 10\% FCS, $1.0 \%$ Triton X-100, and $0.02 \%$ sodium azide. Embryos were incubated for 2 days at $4^{\circ} \mathrm{C}$ and washed three times for $60 \mathrm{~min}$ at $4^{\circ} \mathrm{C}$ in PBS containing $1 \%$ normal goat serum, $1.0 \%$ Triton X-100. For incubation with the secondary antibody, embryos were incubated in a $1: 100$ dilution in PBS containing $1 \%$ normal goat serum, $1.0 \%$ Triton $\mathrm{X}-100$ of peroxidase-conjugated goat antimouse IgG (Sigma) at $4^{\circ} \mathrm{C}$ overnight. Embryos were then washed three times for $60 \mathrm{~min}$ at $4^{\circ} \mathrm{C}$ in $\mathrm{PBS}$ containing $1 \%$ normal goat serum, $1.0 \%$ Triton $\mathrm{X}-100$. To detect the peroxidase reaction, embryos were incubated in diaminobenzidine $500 \mu \mathrm{g} / \mathrm{ml}$ in Tris-buffered saline) for $3 \mathrm{hr}$ at $4^{\circ} \mathrm{C}$ in the dark. To activate the diaminobenzidine, hydrogen peroxide was added to $0.03 \%$ (vol/ vol, , and embryos were observed at room temperature under a dissecting microscope until cranial ganglia and nerves were visible ( $\sim \mathrm{min})$. Embryos were then washed repeatedly in large volumes of PBS, and photographs were taken immediately on an Olympus stereoscope.

\section{In situ hybridization}

Whole-mount in situ hybridization was performed according to the method of Wilkinson (1992), with the following modifica- tions. For 9.0-dpc embryos the time of the proteinase $\mathrm{K}$ treat ment was reduced to $7 \mathrm{~min}$. The time for preblocking the embryos with normal sheep serum was increased to $2.5 \mathrm{hr}$. In addition, to stop the histochemical reaction we found it necessary to store the embryos overnight in low $\mathrm{pH}$ (pH 5.5) PBS-0.1\% Tween 20. The Hoxb-2 probe (Sham et al. 1993) was the gift of Robb Krumlauf (Institute for Medical Research, London, UK). The new Hox gene nomenclature is from Scott (1992).

In situ hybridization of embryo sections was performed as described previously (Franco del Amo et al. 1992; Smith and Gridley 1992). Plasmids were linearized with the appropriate enzymes, and ${ }^{35} S$-labeled transcripts were generated by runoff transcription. The probe for the CRABP I gene consisted of a 750-bp cDNA clone containing the entire coding sequence (Stoner and Gudas 1989; gift of Joe Grippo, Hoffman-La Roche, Inc., Nutley, NI). The sense-strand probe for the Hoxb-3 gene was transcribed from the BamHI-HindIII fragment just downstream of the homeo box (Sham et al. 1992; gift of Robb Krumlauf). The probe for the Fgf3 (int-2) gene was as described (Wilkinson et al. 1988; gift of David Wilkinson, Institute for Medical Research, London, UK|. In situ hybridization probes for Hoxb-1 (Frohman et al. 1990) and Sek (Nieto et al. 1992) were made by reverse transcriptase-polymerase chain reaction (RTPCR). The Hoxb-1 probe was a 435 -nucleotide fragment from the 3' untranslated region of the gene. The Sek probe consisted of nucleotides 1848-2250 of the Sek cDNA (Nieto et al. 1992). Double-exposure photographs /dark field with red filter; bright field with blue filter) were taken on a Zeiss Axioplan microscope.

\section{Acknowledgments}

We thank Drs. Phil Soriano for the PGKneobpa plasmid, Colin Stewart for breeding stock for the $129 / \mathrm{Sv}$ and the transgenic G418-resistant mouse strains, and Andrew Lumsden for the whole-mount immunohistochemistry protocol. We also thank David Wilkinson for the Fgf3 (int-2) in situ hybridization probe, Robb Krumlauf for the Hoxb-2 and Hoxb-3 probes, Joe Grippo for the CRABP I probe, and Maureen Gendron-Maguire for help with the histology.

The publication costs of this article were defrayed in part by payment of page charges. This article must therefore be hereby marked "advertisement" in accordance with 18 USC section 1734 solely to indicate this fact.

\section{References}

Acampora, D., M. D'Esposito, A. Faiella, M. Pannese, E. Migliaccio, F. Morelli, A. Stornaiuolo, V. Nigro, A. Simeone, and E. Boncinelli. 1989. The human HOX gene family. Nucleic Acids Res. 17: 10385-10402.

Bradley, L.C., A. Snape, S. Bhatt, and D.G. Wilkinson. 1992. The structure and expression of the Xenopus Krox-20 gene: Conserved and divergent patterns of expression in rhombomeres and neural crest. Mech. Dev. 40: 73-84.

Chavrier, P., M. Zerial, P. Lemaire, J. Almendral, R. Bravo, and P. Charnay. 1988. A gene encoding a protein with zinc fingers is activated during G0/G1 transition in cultured cells. EMBO /. 7: 29-35.

Chavrier, P., U. Janssen-Timmen, M.-G. Mattei, M. Zerial, R. Bravo, and P. Charnay. 1989. Structure, chromosome location, and expression of the mouse zinc finger gene Krox-20: Multiple gene products and coregulation with the proto-oncogene c-fos. Mol. Cell. Biol. 9: 787-797.

Chavrier, P., C. Vesque, B. Galliot, M. Vigneron, P. Solle, D. Duboule, and P. Charnay. 1990. The segment-specific gene Krox 20 encodes a transcription factor with binding sites in 
the promoter of the Hox 1.4 gene. EMBO J. 9: 1209-1218.

Chisaka, O., T.S. Musci, and M.R. Capecchi. 1991. Developmental defects of the ear, cranial nerves and hindbrain resulting from targeted disruption of the mouse homeobox gene Hox-1.6. Nature 355: 516-520.

Conlon, R.A. and J. Rossant. 1992. Exogenous retinoic acid rapidly induces anterior ectopic expression of murine Hox-2 genes in vivo. Development 116: 357-368.

Dodd, J. and J.P. Kelly. 1991. Trigeminal system. In Principles of neural science, 3rd ed. (ed. E.R. Kandel, J.H. Schwartz and T.M. Jessell), pp. 701-710. Elsevier, New York.

Dodd, J., S.B. Morton, D. Karagogeos, M. Yamamoto, and T. Jessell. 1988. Spatial regulation of axonal glycoprotein expression on subsets of embryonic spinal neurons. Neuron 1: $105-116$

Franco del Amo, F., D.E. Smith, P.J. Swiatek, M. GendronMaguire, R.J. Greenspan, A.P. McMahon, and T. Gridley. 1992. Expression pattern of Motch, a mouse homolog of Drosophila Notch, suggests an important role in early postimplantation mouse development. Development 115: 737744.

Fraser, S., R. Keynes, and A. Lumsden. 1990. Segmentation in the chick embryo hindbrain is defined by cell lineage restrictions. Nature 344: 431-435.

Frohman, M., M. Boyle, and G. Martin. 1990. Isolation of the mouse Hox-2.9 gene: Analysis of embryonic expression suggests that positional information along the anterior-posterior axis is specified by mesoderm. Development 110: 589607.

Guthrie, S. and A. Lumsden. 1991. Formation and regeneration of rhombomere boundaries in the developing chick hindbrain. Development 112: 221-229.

Hunt, P., M. Gulisano, M. Cook, M. Sham, A. Faiella, D. Wilkinson, E. Boncinelli, and R. Krumlauf. 1991. A distinct Hox code for the branchial region of the head. Nature 353: 861-864

Jeffs, P., K. Jaques, and M. Osmond. 1992. Cell death in cranial neural crest development. Anat. Embryol. 185: 583-588.

Joseph, L.J., M.M. Le Beau, G.A. Jamieson Jr., S. Acharya, T.B. Shows, J.D. Rowley, and V.P. Sukhatme. 1988. Molecular cloning, sequencing, and mapping of $E G R 2$, a human early growth response gene encoding a protein with "zinc-binding finger" structure. Proc. Natl. Acad. Sci. 85: 7164-7168.

Kessel, M. 1993. Reversal of axonal pathways from rhombomere 3 correlates with extra Hox expression domains. Neuron 10: 379-393.

Keynes, R. and A. Lumsden. 1990. Segmentation and the origin of regional diversity in the vertebrate central nervous system. Neuron 2: 1-9.

Krumlauf, R. 1993. Hox genes and pattern formation in the branchial region of the vertebrate head. Trends Genet. 9: 106-112.

Kuratani, S.C. and G. Eichele. 1993. Rhombomere transplantation repatterns the segmental organization of cranial nerves and reveals cell-autonomous expression of a homeodomain protein. Development 117: 105-117.

Laird, P.W., A. Zijderveld, K. Linders, M.A. Rudnicki, R. Jaenisch, and A. Berns. 1991. Simplified mammalian DNA isolation procedure. Nucleic Acids Res. 19: 4293.

Lamar, E.E. and E. Palmer. 1984. Y-encoded, species-specific DNA in mice: Evidence that the $\mathrm{Y}$ chromosome exists in two polymorphic forms in inbred strains. Cell 37: 171-177.

Lufkin, T., A. Dierich, M. LeMeur, M. Mark, and P. Chambon. 1991. Disruption of the Hox-1.6 homeobox gene results in defects in a region corresponding to its rostral domain of expression. Cell 66: 1105-1119.
Lumsden, A. 1990. The cellular basis of segmentation in the developing hindbrain. Trends Neurosci. 13: 329-335.

Lumsden, A. and S. Guthrie. 1991. Alternating patterns of cell surface properties and neural crest cell migration during segmentation of the chick hindbrain. Development (Suppl.) 2: 9-15.

Lumsden, A. and R. Keynes. 1989. Segmental patterns of neuronal development in the chick hindbrain. Nature 337: 424 428.

Lumsden, A., N. Sprawson, and A. Graham. 1991. Segmental origin and migration of neural crest cells in the hindbrain region of the chick embryo. Development 113: 1281-1291.

Maden, M. and N. Holder. 1992. Retinoic acid and development of the central nervous system. BioEssays 14: 431-438.

Maden, M., C. Horton, A. Graham, L. Leonard, J. Pizzey, G. Siegenthaler, A. Lumsden, and U. Eriksson. 1992. Domains of cellular retinoic acid-binding protein I (CRABP I) expression in the hindbrain and neural crest of the mouse embryo. Mech. Dev. 37: 13-23.

Mansour, S.L.R., and M.R. Capecchi. 1988. Disruption of the proto-oncogene int- 2 in mouse embryo-derived stem cells: A general strategy for targeting mutations to non-selectable genes. Nature 336: 348-352.

Marshall, H., S. Nonchev, M.H. Sham, I. Muchamore, A. Lumsden, and R. Krumlauf. 1992. Retinoic acid alters hindbrain Hox code and induces transformation of rhombomeres $2 / 3$ into a 4/5 identity. Nature 360: 737-741.

Morriss-Kay, G. 1992. Retinoic acid and craniofacial development: Molecules and morphogenesis. BioEssays 15: 9-15.

Morriss-Kay, G.M., P. Murphy, R.E. Hill, and D.R. Davidson. 1991. Effects of retinoic acid excess on expression of Hox-2.9 and Krox-20 and on morphological segmentation in the hindbrain of mouse embryos. EMBO /. 10: 2985-2995.

Murphy, P., D. Davidson, and R. Hill. 1989. Segment-specific expression of a homeobox-containing gene in the mouse hindbrain. Nature 341: 156-159.

Nardelli, J., T.J. Gibson, C. Vesque, and P. Charnay. 1991. Base sequence discrimination by zinc-finger DNA-binding domains. Nature 349: 175-178.

Nardelli, J., T. Gibson, and P. Charnay. 1992. Zinc finger-DNA recognition: Analysis of base specificity by site-directed mutagenesis. Nucleic Acids Res. 20: 4137-4144.

Nieto, M.A., L.C. Bradley, and D.G. Wilkinson. 1991. Conserved segmental expression of Krox-20 in the vertebrate hindbrain and its relationship to lineage restriction. Development (Suppl.) 2: 59-62.

Nieto, M.-A., P. Gilardi-Hebenstreit, P. Charnay, and D. Wilkinson. 1992. A receptor protein tyrosine kinase implicated in the segmental patterning of the hindbrain and mesoderm. Development 116: 1137-1150.

Oxtoby, E. and T. Jowett. 1993. Cloning of the zebrafish krox-20 gene $(k r x-20)$ and its expression during hindbrain development. Nucleic Acids Res. 21: 1087-1095.

Papalopulu, N., J.D.W. Clarke, L. Bradley, D. Wilkinson, R. Krumlauf, and N. Holder. 1991. Retinoic acid causes abnormal development and segmental patterning of the anterior hindbrain in Xenopus embryos. Development 113: 11451158.

Pavletich, N.P. and C.O. Pabo. 1991. Zinc finger-DNA recognition: Crystal structure of a Zif268-DNA complex at $2.1 \mathrm{~A}$. Science 252: 809-817.

Robertson, E.J. 1987. Embryo-derived stem cell lines. In Teratocarcinomas and embryonic stem cells: A practical approach (ed. E.J. Robertson), pp. 71-112. IRL Press, Oxford, UK.

Role, L.W. and J.P. Kelly. 1991. The brain stem: Cranial nerve 
nuclei and the monoaminergic systems. In Principles of neural science, 3rd ed. (ed. E.R. Kandel, J.H. Schwartz, and T.M. Jessell), pp. 683-699. Elsevier, New York.

Ruberte, E., V. Friederich, G. Morriss-Kay, and P. Chambon. 1992. Differential distribution patterns of CRABP I and CRABP II transcripts during mouse embryogenesis. Development 115: 973-987.

Sambrook, J., E.F. Fritsch, and T. Maniatis. 1989. Molecular cloning: A laboratory manual Cold Spring Harbor Laboratory Press, Cold Spring Harbor, New York.

Scott, M. 1992. Vertebrate homeobox gene nomenclature. Cell 71: 551-553.

Sechrist, J., G.N. Serbedzija, T. Scherson, S.E. Fraser, and M. Bronner-Fraser. 1993. Segmental migration of the hindbrain neural crest does not arise from its segmental generation. Development 118: 691-703.

Serbedzija, G.N., M. Bronner-Fraser, and S.F. Fraser. 1992. Vital dye analysis of cranial neural crest cell migration in the mouse embryo. Development 116: 297-307.

Sham, M.H., P. Hunt, S. Nonchev, N. Papalopulu, A. Graham, E. Boncinelli, and R. Krumlauf. 1992. Analysis of the murine Hox-2.7 gene: Conserved alternative transcripts with differential distributions in the nervous system and the potential for shared regulatory regions. EMBO J. 11: 1825-1836.

Sham, M.H., C. Vesque, S. Nonchev, H. Marshall, M. Frain, R.D. Gupta, J. Whiting, D. Wilkinson, P. Charnay, and R. Krumlauf. 1993. The zinc finger gene Krox20 regulates HoxB2 (Hox-2.8) during hindbrain segmentation. Cell 72: $183-196$.

Smith, S. and G. Eichele. 1991. Temporal and regional differences in the expression pattern of distinct retinoic acid receptor-beta transcripts in the chick embryo. Development 111: 245-252.

Smith, D.E. and T. Gridley. 1992. Differential screening of a PCR-generated mouse embryo cDNA library: Glucose transporters are differentially expressed in early postimplantation mouse embryos. Development 116: 555-561.

Soriano, P., C. Montgomery, R. Geske, and A. Bradley. 1991. Targeted disruption of the c-src proto-oncogene leads to osteopetrosis in mice. Cell 64: 693-702.

Stewart, C.L., P. Kaspar, L.J. Brunet, H. Bhatt, I. Gadi, F. Kontgen, and S.J. Abbondanzo. 1992. Blastocyst implantation depends on maternal expression of leukemia inhibitory factor. Nature 359: 76-79.

Stoner, C.M. and L.J. Gudas. 1989. Mouse cellular retinoic acidbinding protein: cloning, complementary DNA sequence and messenger RNA expression during the retinoic acid-in duced differentiation of F9 wild-type and RA-3-10 mutant teratocarcinoma cells. Cancer Res. 49: 1497-1504.

Sundin, O. and G. Eichele. 1990. A homeodomain protein reveals the metameric nature of the developing chick hindbrain. Genes \& Dev, 4: 1267-1276.

- 1992. An early marker of axial pattern in the chick embryo and its respecification by retinoic acid. Development 114: 841-852.

Vaage, S. 1969. The segmentation of the primitive neural tube in chick embryos (Gallus domesticus). Adv. Anat. Embryol. Cell Biol. 41: 1-88.

Vesque, C. and P. Charnay. 1992. Mapping functional regions of the segment-specific transcription factor Krox20. Nucleic Acids Res. 20: 2485-2492.

Wilkinson, D.G. 1992. Whole mount in situ hybridization of vertebrate embryos. In In situ hybridization: A practical approach (ed. D.G. Wilkinson), pp. 75-83. IRL Press, Oxford, UK.

_ 1993. Molecular mechanisms of segmental patterning in the vertebrate hindbrain and neural crest. BioEssays 15: 499-505.

Wilkinson, D. and R. Krumlauf. 1990. Molecular approaches to the segmentation of the hindbrain. Trends Neurosci. 13: 335-339.

Wilkinson, D., G. Peters, C. Dickson, and A. McMahon. 1988. Expression of the FGF-related proto-oncogene int-2 during gastrulation and neurulation in the mouse. EMBO I. 7: 691695.

Wilkinson, D.G., S. Bhatt, P. Chavrier, R. Bravo, and P. Charnay. 1989a. Segment-specific expression of a zinc finger gene in the developing nervous system of the mouse. Nature 337: 461-465.

Wilkinson, D., S. Bhatt, M. Cook, E. Boncinelli, and R. Krumlauf. 1989b. Segmental expression of Hox-2 homeobox-containing genes in the developing mouse hindbrain. Nature 341: 405-409.

Williams, P.L. and R. Warwick. 1980. Gray's anatomy, 36th ed. W.B. Saunders Co., Philadelphia, PA. 


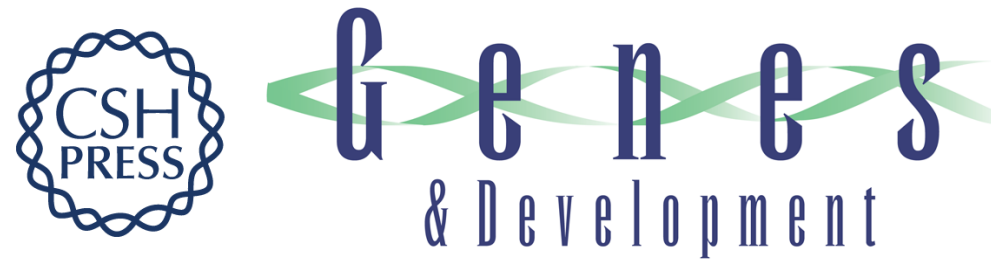

\section{Perinatal lethality and defects in hindbrain development in mice homozygous for a targeted mutation of the zinc finger gene Krox20.}

P J Swiatek and T Gridley

Genes Dev. 1993, 7:

Access the most recent version at doi:10.1101/gad.7.11.2071

References This article cites 60 articles, 19 of which can be accessed free at:

http://genesdev.cshlp.org/content/7/11/2071.full.html\#ref-list-1

License

Email Alerting

Service

Receive free email alerts when new articles cite this article - sign up in the box at the top right corner of the article or click here.

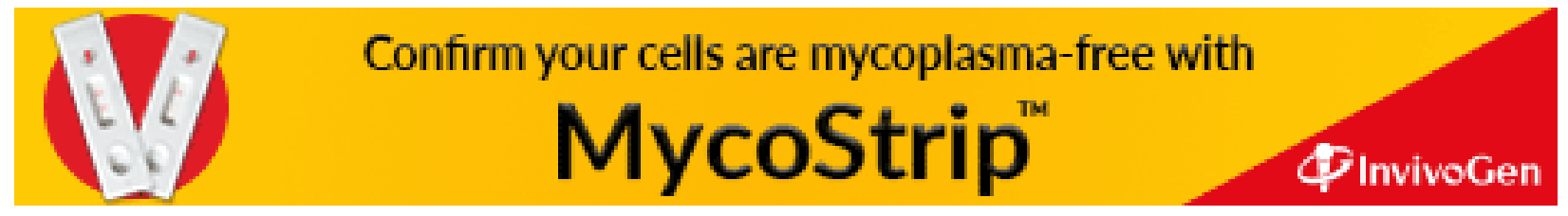

